\title{
Indoor air quality monitoring and human perception survey on air quality in public buildings in Timisoara
}

\author{
Iudit Bere - Semeredi 1,*, Mihai Eugen Valceanu ${ }^{2}$, Diana Mihaela Nica $^{2}$, Ella Anca Sipetan ${ }^{2}$, \\ and Romulus Corlan ${ }^{3}$ \\ ${ }^{1}$ Politehnica University of Timisoara, Faculty of Management in Production and Transportation, 14 \\ Remus str., 300191 Timisoara, Romania \\ ${ }^{2}$ The City Hall of Timisoara, Environmental Directorate, 1 Constantin Diaconovici Loga Bd., 300030 \\ Timisoara, Romania \\ 3 Politehnica University of Timisoara, Faculty of Electrical and Power Engineering, \\ 2 Vasile Parvan Bd., 300223 Timisoara, Romania
}

\begin{abstract}
The paper presents a study aimed at investigating the indoor air quality (IAQ) and people's perception regarding the indoor environment of schools and public buildings in Timisoara. The indoor air quality monitoring was performed during the cold season, in the period January 2020 - February 2021. Six public buildings - schools and administrative edifices belonging to the municipality were subject of monitoring. An Andersen microbial air sampler was used to enumerate the numbers and different kinds of respirable bacteria and fungi inside of the selected classrooms and offices. The results of the specialized laboratory analyses indicate that the microbiological contaminant counts, expressed in colonyforming unit $\left(\mathrm{CFU} / \mathrm{m}^{3}\right)$, fall within the permissible limits for all monitored rooms. No beta-hemolytic streptococci or Staphylococcus aureus were identified, conditionally pathogenic bacteria for the upper respiratory tract. Most moulds were of the genus Penicillium, without having a pathogenic significance for humans. Occupants' perception on indoor air quality, thermal comfort, health complaints and symptoms such allergies or respiratory illnesses with possible connection to the Sick building syndrome were surveyed by questionnaire. The findings were analysed and a plan to improve IAQ in the public buildings was proposed, with specific measures to increase the comfort and health of the learning and working environment.
\end{abstract}

\section{Introduction}

Indoor Air Quality (IAQ) and Indoor Air Pollution (IAP) monitoring have been fields of interest over the last decade. This interest is justified by the fact that there is a tangible connection between indoor air quality and the health and wellbeing of the inhabitants. Determination of bacterial load in the indoor environment of public buildings - schools and

\footnotetext{
* Corresponding author: iudit.bere-semeredi@student.upt.ro
} 
administrative buildings offices - is necessary to estimate the health risk and to implement measures and actions to improve indoor air quality.

Clean air is fundamental to healthy human life [1]. Indoor air quality has been the objective of several surveys especially after the increasing concern within the health care communities related to the effects of indoor air quality upon health. People spend nowadays more time indoors than they do in open air. Children spend more than $20 \%$ of the time at school, adults more than $80 \%$ in indoor environments, especially in the last year, due to the restriction of free movement in response to the COVID-19 pandemic.

Indoor air pollution is defined by physical, chemical, inorganic compounds, particulate matter, volatile organic compounds (VOCs) and bioaerosol particles. All of these negatively affect the human body, depending on the degree in which they are present the indoor air. The exposure to high concentrations and/or long-term exposure to indoor air pollutants can cause acute respiratory exacerbations in people.

Specialty literature indicates that a healthy adult inhale an average of 10,000-20,0000 1 of air per day [2-3]. The upper respiratory tract (URT) is constantly bathed by the flow of air from the external environment. For every cubic meter of air inhaled, 104-106 bacterial cells enter the respiratory tract. In our daily lives, our bodies are impacted by various aerosols in different forms: liquid and solid, inorganic and organic, viable and nonviable [3], which influence our environment. The particles commonly found in the indoor environment are bacteria, spores, fine particles and viruses. Some of these can cause infections while others do not.

Numerous studies have shown that the fungi more commonly isolated from indoor microaeroflora belong to the Alternaria, Aspergillus, Cladosporium, Fusarium, Penicillium, Stachybotrys, Ullocladium and Trichoderma genera [4,5]. Most of these species were investigated in our monitoring survey as well. In 2008, Simon-Nobbe [6] and collab. reported nearly 150 species of allergenic fungi. Among them some species of Alternaria, Aspergillus, Cladosporium and Penicillium may be associated with the production of allergens [6]. For example, Aspergillus fumigatus has been linked to severe or persistent forms of asthma [7]. Alternaria has also been reported to be responsible for the development of severe forms of asthma in people exposed for a long time to this type of mould.

In terms of bacteria, the side effects on health are like those mentioned for fungi. The release of airborne compounds into the cell wall structure of bacteria or the production of toxins can cause respiratory conditions [8-10]. Gram-negative bacteria can frequently contaminate indoor air, and by releasing endotoxins into the air from the wall, they can cause inflammation of the respiratory mucosa [11-13]. These health problems represent a high economic impact all over the world [14,15]. It is therefore important to assess the presence of potentially pathogenic microorganisms in schools, kindergartens, offices, workplaces and public spaces and to implement solutions and measures to prevent or control the development of these organisms.

Air, the route of transmission for many microorganisms, plays a very important epidemiological role. Infectious diseases with aerial transmission occupy the first place in frequency, representing about $20 \%$ of infectious pathology. The persistence in the air of microorganisms depends on several factors, such as temperature and humidity. In general, air does not provide conditions for the development of the microbial-aeroflora. The air temperature, however, can undergo large variations reaching optimal temperatures for the metabolism of mesophilic flora $\left(35^{\circ} \mathrm{C}-40^{\circ} \mathrm{C}\right)$. Air humidity also does not meet the requirements of bacteria of human habitat due to the low relative humidity $(\mathrm{RH})$ values and the permanent variations it registers. Ultraviolet radiation has bactericidal action on airborne pathogens thus we cannot talk about the aerial development of microorganisms, but only a possible resistance to environmental factors. 
In the atmosphere, the number of microorganisms decreases rapidly, being quickly destroyed, and because of dilution. For these reasons, outdoors, where negative factors have a more pronounced action and where dilution is significant, the pathogenic aeroflora is less isolated than in the enclosed spaces. Thus, the flora inside enclosed environments plays the main role in the aerogenic transmission of infectious diseases, especially under conditions of congestion and insufficient air ventilation. When we discuss about adequate ventilation, we must underline the fact that nowadays air conditioning and ventilation could be a challenge, due to the poor outdoor air quality and the actual trend of energy consumption reduction, an objective for the transition to a low carbon economy.

Aero-microflora is an important health problem in communities such as: schools, kindergartens, nurseries, and public institutions, where the aerial transmission of pathogens is favoured by the interpersonal contact. The sources of the pathogens circulated through the air come from the upper respiratory tract (URT), oral cavity, skin flora as well as indoor plants or contaminated surfaces. There is also a certain accidentally pathogenic flora of a ubiquitous nature, such as fungi involved in the etiology of extrinsic allergic alveolitis (EAA).

Recent studies revealed that airborne microorganisms can be carried by dust particle and can impact human health via pathogenesis, and the development of sensitivities in the case of prolonged exposure, and airborne fungal and bacterial spores can cause a series of allergic reactions.

In general, in communities, the microorganisms in the air adhere to a certain substrate: droplets of nasopharyngeal or bronchial secretion, eliminated during speech, coughing, sneezing, and even singing [16] (so called Flügge droplets) to a distance $>1 \mathrm{~m} \mathrm{[17].} \mathrm{The}$ droplet nuclei (droplets $\leq 5 \mu \mathrm{m}$ ) derived from the evaporation of smaller droplets of nasopharyngeal or bronchial secretion. Study results suggested that sneezing may produce even 40,000 droplets between $0.5-12 \mu \mathrm{m}$ in diameter [18-19] and expelled at speeds up to $100 \mathrm{~m} / \mathrm{s}$.

In other cases, the microorganism is attached to dust particles (microbial powders) [16]. In this situation, microorganisms can come from droplets or the droplet nuclei deposited on the floor of the room, from dry nasopharyngeal secretions. Large dust particles are deposited quickly, while smaller particles remain in the air for a longer time. Dust deposited on the floor of a room can be brought back into the air during sweeping or due to air currents. Numerous particles of contaminated dust can also reach the air when carpets are shaken.

Although not a good environment for the multiplication and survival of germs for a long time, air is a good transmitter, especially for etiological agents of infections with respiratory entry gates or elimination pathways: influenza, common respiratory viruses, measles, rubella, chickenpox, whooping cough, meningococcal meningitis, staphylococcal and streptococcal infections.

The determination of the total germs number (TGN) in the indoor air, developed at $37^{\circ} \mathrm{C}$ also called mesophilic flora, allow the appreciation of the degree in which the air is charged with flora of human origin.

Following few studies realized in Europe [20,21], the interest for IAQ and IEP increased, the studies realized showing a clear linkage between poor air quality and health issues reported by the occupants [22-24].

Using the knowledge of previous studies, the objective of our study was to analyse the actual status of IAQ and microaeroflora in public buildings - schools and public institutions, to perform a comparative analysis of local results against the norms on microbial air content and to assess the perception of the occupants regarding the air quality inside the buildings, considering the fact that air quality represents a determinant factor in 
human health and well-being. To that end, the study was conducted with the active involvement of local decision - makers, workers, public employees, teachers and students.

\section{Materials and Methods}

\subsection{Survey context}

The Municipality of Timisoara implemented the project named "Smart and Sustainable Energy Consumption" (SASEC, RORS-300), in the frame of Interreg IPA Cross-border Cooperation Program Romania - Serbia 2014-2020. The project activities were circumscribed to the concepts of energy efficiency, responsible energy consumption, research on environmental resources and energy savings. One of the project goals was to investigate the air quality inside six schools from Timisoara and Zrenjanin. The changes that occurred in the educational process after March 2020, because of the state of emergency, respectively national alert, applied in the context of the COVID-19 pandemic, produced major changes including in the activity of schools, by switching to online education. Therefore, out of the 6 forecasted companies, only four targeted the schools, two campaigns being dedicated to three public institutions belonging to the municipality.

\subsection{Bacteriological analysis of the air}

The air samplings were realized during six campaigns, in the winter months: January, February, second half of November, and December 2020, respectively January and February 2021.

During the survey, microbial aeroflora was investigated, because the composition and density of the aeroflora is direct depends on the existence of human communities, especially high-density communities, as well as the hygiene measures implemented.

Bacteriological analysis of the indoor air realized in the public buildings of Timisoara allows assessment of the hygienic-sanitary risk that the environment must allow the airborne transmission of infections.

The scope was for the assessment of working and studying conditions in the six public institutions and educational establishments from Timisoara.

The survey intended to establish the potential for aerogenous transmission of pathogens and conditional pathogens, identification of certain bacteriological indicators, and to quantify the loading of air with microbial flora.

For this purpose, certain bacteriological indicators of air contamination were monitored:

- The total number of germs (TNG) in the air that develop at $37^{\circ} \mathrm{C}$ (mesophilic flora).

- Streptococcus, an indicator of contamination of the air with flora from the respiratory and oral cavity.

- Staphylococcus normally colonizes the mucosa of the URT and the skin. Most staphylococcus species are non-pathogenic or accidentally pathogenic (coagulase-negative staphylococci), the only conditionally pathogenic species being Staphylococcus aureus, which is frequently involved in the etiology of respiratory and skin infections. The resistance of staphylococcus to the external environment being relatively high, they constantly contaminate the human living environment, e.g., the air. The significance of staphylococcus isolation in the aeroflora is like that of mesophilic microorganisms, but more accurately indicating the human origin of air contamination. Through the microbiological analysis of the air all staphylococci were isolated, but it was important to identify the species of Staphylococcus aureus. 
- Coliform germs. Their presence in the microaeroflora indicates a degree of environmental sanitation and can assess the degree of cleanliness in the classrooms and offices.

The determination of the total germs number (TGN) in the indoor air, developed at $37^{\circ} \mathrm{C}$ also called mesophilic flora, allowed the appreciation of the degree in which the air was charged with flora of human origin.

- Fungi (moulds) and yeasts (Candida sp.).

\subsection{Air sampling procedure}

The air sampling was realized using the MAS-100 ECO equipment from two points of each classroom and office (centre and corner), followed by the labelling, packaging, sealing and transport of the Petri dishes under optimal temperature conditions, to be processed in the Central Laboratory of Medical Analysis of the Emergency County Clinical Hospital "Pius Brinzeu" Timisoara, Romania.

For sampling, a MAS-100 ECO sampling instrument, a small, lightweight and performant air sampler owned by the City Hall of Timisoara was used. The MAS-100 ECO sampling instrument uses the Anderson principle of air sampling through a perforated filter. The air sampling speed (the rate at which airborne microorganisms hit the agar surface) was approximately $11 \mathrm{~m} / \mathrm{s}$, a speed that ensures that all particles $>1 \mu \mathrm{m}$ are collected, and the particle-carrying air flow was directed to the Petri dish with the culture environment. MAS100 is a performant equipment that was designed specifically for determining low CFU counts.

To get reliable results, the sampling equipment was used around one meter above the ground. Two measurements points were selected in each investigated classroom and office: one from the central areas of the room and one from one corner. The air samplings were conducted during the class courses and working hours, between 09:00 and 13:00.

In the air quality survey, 10 parameters were monitored, and 5 isolation environments were used (Table 1).

Table 1. Parameters and isolation environment.

\begin{tabular}{|c|c|}
\hline Parameters & Isolation environments \\
\hline Total CFU "colony-forming units" & Simple Agar \\
\hline $\begin{array}{c}\text { Staphylococcus aureus/Coagulase- } \\
\text { Negative Staphylococci }\end{array}$ & $\begin{array}{l}\text { Chapman (Manitol Salt Agar)/Blood Agar } \\
\text { (Agar with 5\% defibrinate blood of ram) }\end{array}$ \\
\hline $\begin{array}{l}\text { Streptococcus } \alpha \text {-hemolytics and } \\
\beta \text {-hemolytics }\end{array}$ & $\begin{array}{c}\text { Blood Agar (Agar with 5\% defibrinate blood } \\
\text { of ram) }\end{array}$ \\
\hline Enterococci & CHROM agar (UTI) \\
\hline Bacillus cereus/Bacillus sp. & $\begin{array}{c}\text { Blood Agar (Agar with 5\% defibrinate blood } \\
\text { of ram) }\end{array}$ \\
\hline Coliforms (Escherichia coli) & CHROM Agar (UTI) \\
\hline Gram-negative bacilli & CHROM Agar (UTI) \\
\hline Pseudomonas aeruginosa & $\begin{array}{c}\text { Blood Agar (Agar with } 5 \% \text { defibrinate blood } \\
\text { of ram)/CHROM agar (UTI) }\end{array}$ \\
\hline Fungi (moulds) & Sabouraud Agar with Chloramphenicol \\
\hline Yeasts (Candida sp.) & Sabouraud Agar with Chloramphenicol \\
\hline
\end{tabular}

For all determinations, Petri dishes with culture environments (Sanimed/BioMaxima) were used intended to count, isolate, and identify bacteria and fungi (as shown in Table 1). The incubation of the dishes for isolation for bacteria was achieved in the thermostat with $\mathrm{CO}_{2}$ - Sanyo MCO175 at $35 \pm 2^{\circ} \mathrm{C}$, and for fungi in the Caloris TC50 Thermostat at $28 \pm 2^{\circ} \mathrm{C}$. 
The identification was based on culture characters, morpho-tinctorial characters on Gram coloured smears, pathogenicity tests and metabolic properties. The species-level establishment of microorganisms involved agglutination tests to establish streptococci groups, determination of coagulase for staphylococcus, biochemical tests for the identification of Gram-negative bacteria or fungi (API tests, Vitek 2 Compact cards). This activity was carried out by the specialist from the Central Laboratory of Medical Analysis of the Emergency County Clinical Hospital "Pius Brînzeu" Timisoara.

During the six campaigns, the temperature and relative humidity were monitored in parallel with the microbiological determinations. For the better interpretation of the results the technical data of the buildings, the degree of agglomeration in the interiors, the air sampling season and in particular the preventive measures applied during the context of the pandemic we are currently facing were also needed.

Sampling and measurements were made in occupied rooms of the buildings, in representative sample of each location (basement, ground floor, first floor and attic).

\section{Sanitary norms}

For bacterial air content there are no national or European standards so far. Indicative rules have been developed based on which the degree of air contamination can be assessed. These include the total number of germs with the indication of hemolytic species, in particular $\beta$-hemolytic streptococcus and Staphylococcus aureus.

I. A. Safir proposes the following values for living spaces:

Table 2. Norms on microbial air content (UFC number at $37^{\circ} \mathrm{C} / \mathrm{m}^{3}$ ) and of viridans and $\beta$-hemolytic streptococci in air $\left(\mathrm{UFC} / \mathrm{m}^{3}\right)$.

\begin{tabular}{|c|c|c|c|}
\hline Sanitary norms & Status & Summer & Winter \\
\hline Norms on microbial air content (number & Clean & 1,500 & 4,500 \\
\cline { 2 - 4 } of CFU at $\left.37^{\circ} \mathrm{C} / \mathrm{m}^{3}\right)$ & Impurified & 2,500 & 7,000 \\
\hline \multirow{2}{*}{$\begin{array}{c}\text { Norms on the content of viridans and } \beta- \\
\text { haemolytic streptococci in air }\left(\mathrm{UFC} / \mathrm{m}^{3}\right)\end{array}$} & Clean & 16 & 36 \\
\cline { 2 - 4 } & Impurified & 36 & 124 \\
\hline
\end{tabular}

The differences between summer and winter are explained by the lower ventilation during winter, not justified in the current context. The average, in living spaces and public spaces, for mesophilic micro-organisms must not exceed $2,500 / \mathrm{m}^{3}$.

In school, air contamination between 1,500 and 2,000 UFC is accepted at $37^{\circ} \mathrm{C} / \mathrm{m}^{3}$.

Table 3. Indicative rules for fungal loading of air of rooms [25].

\begin{tabular}{|c|c|}
\hline Normal values & $<550$ colonies $/ \mathrm{m}^{3}$ air \\
\hline Average infestation & $550-700$ colonies $/ \mathrm{m}^{3}$ air \\
\hline Maximum infestation & $>700$ colonies $/ \mathrm{m}^{3}$ air \\
\hline
\end{tabular}

Indoor Air quality (IAQ) problems are more and more common in public building schools and offices, and may negatively influence the performance of pupils, teachers, and employees. Beside the air quality - from microbiological point of view, several environmental factors are adversely affecting the occupants, like thermal conditions, lighting quality, dampness and mould, diverse odours, and thermal conditions.

Numerous studies have shown that there is a clear association between air quality in schools and buildings and the quality of environmental factors, especially thermal conditions: too high or too low indoor temperature, too high or low air humidity, presence 
of mould and a lack of maintenance, obsolete furniture, and an increase in the number of respiratory symptoms in children and adults.

\section{Results on microaeroflora investigation}

- The total number of germs (TNG), expressed in $\mathrm{CFU} / \mathrm{m}^{3}$, counted during the air quality survey was within the limits allowed, in all public institutions investigated;

- Higher values $\left(\mathrm{CFU} / \mathrm{m}^{3}\right)$ were registered in the first two months of the survey, corresponding to the period of manifestation of common respiratory viruses, preceding the implementation of preventive measures in the context of the SARS-CoV-2 pandemic.

- The level of microorganisms in enclosed spaces is closely related to the degree of occupancy of the rooms.

- The presence of Gram-negative bacteria was insignificant in the present survey, as they were rarely isolated and each time in very small quantities. Microbial biodiversity also appears to be a factor involved in allergic conditions.

- The vast majority of bacteria identified were of a non-pathogenic or conditionally pathogenic genera and species. Among the species identified we mention streptococci viridans, coagulase-negative staphylococci, Bacillus cereus - their concentrations being insignificant and not dangerous to the health.

- Among the fungi, moulds prevailed, more commonly isolated being the species of Penicillium, Aspergillus and Rhizopus, also in low concentrations.

- In regard to the educational establishments, following the analysis of all the results obtained in the four campaigns, in the current pandemic context, we note a significant decrease in microbial flora, because of measures to prevent the spread of SARS-CoV-2 infection: the obligation to wear face masks, the intensification of procedures for cleaning and disinfection, the reduction of the number of people in rooms, ending with the transition to online school.

- The household waste collected inside the classrooms and offices in open collecting recipients, dust, along with daily activities/movements influence the number of microorganisms in the air of the classrooms and offices;

- Constant dust removal, regular decontamination, proper periodic ventilation, use of UV lamps and compliance with personal and collective hygiene rules limit the role of air in the transmission of infectious diseases;

The results on IAQ surveys in local public buildings are reflected in Table 4, and the result on IAQ monitoring in schools are reflected in Table 5.

Table 4. Results on IAQ survey - microaeroflora - local public administrative buildings, performed in December 2020 and January 2020.

\begin{tabular}{|c|c|c|c|c|c|c|c|c|c|}
\hline Public buildings & \multicolumn{3}{|c|}{ Building A } & \multicolumn{3}{|c|}{ Building B } & \multicolumn{3}{|c|}{ Building C } \\
\hline Investigated office room & 1 & 2 & 3 & 1 & 2 & 3 & 1 & 2 & 3 \\
\hline Parameter $\left(\mathrm{CFU} / \mathrm{m}^{3}\right) /$ Type & \multicolumn{9}{|c|}{ Total number of germs (TNG) } \\
\hline \multicolumn{10}{|c|}{ Campaign no. 4: 18.12 .2020} \\
\hline Total CFU $/ \mathrm{m}^{3}$ (bacteria) & 126 & 142 & 82 & 64 & 50 & 57 & 248 & 94 & 107 \\
\hline $\begin{array}{l}\text { Alpha-hemolytic Streptococci } \\
\text { / Nonhemolytic Streptococci }\end{array}$ & 7 & 7 & 13 & 5 & 2 & 4 & 16 & 3 & 1 \\
\hline $\begin{array}{c}\text { Coagulase-Negative } \\
\text { Staphylococci }\end{array}$ & 117 & 134 & 67 & 57 & 48 & 53 & 228 & 91 & 14 \\
\hline Total CFU $/ \mathrm{m}^{3}$ (moulds) & 17 & 6 & 2 & 4 & 1 & 27 & 26 & 4 & 12 \\
\hline Aspergillus & 3 & 0 & 1 & 1 & 0 & 9 & 19 & 2 & 1 \\
\hline Penicillium & 14 & 1 & 0 & 1 & 1 & 18 & 6 & 2 & 9 \\
\hline
\end{tabular}




\begin{tabular}{|c|c|c|c|c|c|c|c|c|c|}
\hline Total CFU/m³ (Candida sp.) & 0 & 0 & 0 & 0 & 0 & 0 & 0 & 0 & 0 \\
\hline \multicolumn{10}{|c|}{ Campaign no. 5: 26.01.2021 } \\
\hline Total CFU $/ \mathrm{m}^{3}$ (bacteria) & 170 & 99 & 37 & 62 & 45 & 27 & 178 & 84 & 108 \\
\hline $\begin{array}{l}\text { Alpha-hemolytic Streptococci } \\
\text { / Nonhemolytic Streptococci }\end{array}$ & 6 & 0 & 2 & 3 & 0 & 0 & 6 & 2 & 8 \\
\hline $\begin{array}{l}\text { Coagulase-Negative } \\
\text { Staphylococci }\end{array}$ & 162 & 96 & 35 & 56 & 43 & 25 & 159 & 82 & 95 \\
\hline Total CFU $/ \mathrm{m}^{3}$ (moulds) & 43 & 28 & 3 & 2 & 4 & 2 & 2 & 3 & 1 \\
\hline Aspergillus & 0 & 0 & 0 & 1 & 0 & 0 & 1 & 1 & 0 \\
\hline Penicillium & 30 & 28 & 3 & 0 & 4 & 0 & 0 & 2 & 0 \\
\hline Total CFU/m³ (Candida sp.) & 0 & 0 & 0 & 0 & 0 & 0 & 0 & 0 & 0 \\
\hline
\end{tabular}

Table 5. Results on IAQ survey - microaeroflora in the three schools, four campaigns performed in January 2020, February 2020, November 2020, and February 2021.

\begin{tabular}{|c|c|c|c|c|c|c|c|c|c|}
\hline \multirow{2}{*}{ Investigated classroom } & \multicolumn{3}{|c|}{ School A } & \multicolumn{3}{|c|}{ School B } & \multicolumn{3}{|c|}{ School C } \\
\hline & 1 & 2 & 3 & 1 & 2 & 3 & 1 & 2 & 3 \\
\hline Parameter $\left(\mathrm{CFU} / \mathrm{m}^{3}\right) /$ Type & \multicolumn{9}{|c|}{ Total number of germs (TNG) } \\
\hline \multicolumn{10}{|c|}{ Campaign no. 1: 29.01.2020-30.01.2020 } \\
\hline Total CFU $/ \mathrm{m}^{3}$ (bacteria) & 173 & 157 & 277 & 125 & 667 & 1.188 & 687 & 540 & 151 \\
\hline $\begin{array}{l}\text { Alpha-hemolytic Streptococci } \\
\text { / Nonhemolytic Streptococci }\end{array}$ & 46 & 80 & 98 & 40 & 60 & 79 & 87 & 44 & 39 \\
\hline $\begin{array}{c}\text { Coagulase-Negative } \\
\text { Staphylococci }\end{array}$ & 108 & 49 & 99 & 62 & 491 & 870 & 379 & 444 & 89 \\
\hline Total CFU/m $\mathrm{m}^{3}$ (moulds) & 13 & 8 & 10 & 11 & 2 & 19 & 15 & 24 & 149 \\
\hline Aspergillus & 0 & 1 & 2 & 0 & 0 & 2 & 1 & 1 & 1 \\
\hline Penicillium & 7 & 1 & 1 & 5 & 0 & 14 & 7 & 13 & 147 \\
\hline Total CFU $/ \mathrm{m}^{3}$ (Candida sp.) & 0 & 0 & 0 & 0 & 0 & 0 & 1 & 0 & 0 \\
\hline \multicolumn{10}{|c|}{ Campaign no. 2: 25.02.2020 } \\
\hline Total CFU $/ \mathrm{m}^{3}$ (bacteria) & 68 & 389 & 153 & 195 & 402 & 493 & 101 & 125 & 198 \\
\hline $\begin{array}{l}\text { Alpha-hemolytic Streptococci/ } \\
\text { Nonhemolytic Streptococci }\end{array}$ & 38 & 219 & 48 & 125 & 264 & 244 & 41 & 72 & 138 \\
\hline $\begin{array}{c}\text { Coagulase-Negative } \\
\text { Staphylococci } \\
\end{array}$ & 22 & 111 & 68 & 53 & 82 & 164 & 45 & 40 & 37 \\
\hline Total CFU/m $\mathrm{m}^{3}$ (moulds) & 9 & 13 & 17 & 13 & 22 & 42 & 197 & 28 & 20 \\
\hline Aspergillus & 0 & 0 & 0 & 0 & 5 & 1 & 0 & 0 & 0 \\
\hline Penicillium & 3 & 4 & 3 & 12 & 8 & 37 & 196 & 23 & 8 \\
\hline Total CFU/m³ (Candida sp.) & 0 & 8 & 0 & 2 & 1 & 27 & 0 & 0 & 4 \\
\hline \multicolumn{10}{|c|}{ Campaign no. 3: 18.11.2020 } \\
\hline Total CFU $/ \mathrm{m}^{3}$ (bacteria) & 75 & 60 & 71 & 50 & 69 & 47 & 15 & 23 & 31 \\
\hline $\begin{array}{l}\text { Alpha-hemolytic Streptococci } \\
\text { / Nonhemolytic Streptococci }\end{array}$ & 0 & 2 & 0 & 0 & 0 & 0 & 0 & 0 & 0 \\
\hline $\begin{array}{c}\text { Coagulase-Negative } \\
\text { Staphylococci }\end{array}$ & 75 & 58 & 70 & 46 & 68 & 47 & 15 & 21 & 31 \\
\hline Total CFU $/ \mathrm{m}^{3}$ (moulds) & 0 & 1 & 5 & 3 & 2 & 2 & 0 & 74 & 2 \\
\hline Aspergillus & 0 & 0 & 1 & 0 & 0 & 0 & 0 & 1 & 0 \\
\hline Penicillium & 0 & 0 & 0 & 0 & 0 & 1 & 0 & 70 & 1 \\
\hline Total CFU/m³ (Candida sp.) & 0 & 0 & 0 & 0 & 0 & 0 & 0 & 0 & 0 \\
\hline \multicolumn{10}{|c|}{ Campaign no. 6: 09.02.2021 } \\
\hline Total CFU $/ \mathrm{m}^{3}$ (bacteria) & 48 & 41 & 14 & 58 & 88 & 68 & 210 & 270 & 18 \\
\hline
\end{tabular}




\begin{tabular}{|c|c|c|c|c|c|c|c|c|c|}
\hline $\begin{array}{c}\text { Alpha-hemolytic Streptococci } \\
\text { / Nonhemolytic Streptococci }\end{array}$ & 0 & 0 & 2 & 3 & 20 & 1 & 9 & 7 & 1 \\
\hline $\begin{array}{c}\text { Coagulase-Negative } \\
\text { Staphylococci }\end{array}$ & 45 & 38 & 11 & 48 & 62 & 62 & 195 & 247 & 16 \\
\hline Total CFU/m ${ }^{3}$ (moulds) & 55 & 8 & 3 & 30 & 242 & 4 & 16 & 78 & 2 \\
\hline Aspergillus & 1 & 0 & 1 & 0 & 0 & 0 & 0 & 0 & 0 \\
\hline Penicillium & 52 & 0 & 2 & 28 & 240 & 3 & 16 & 78 & 1 \\
\hline Total CFU/m ${ }^{3}$ (Candida sp.) & 0 & 0 & 0 & 0 & 0 & 0 & 0 & 0 & 0 \\
\hline
\end{tabular}

\section{Investigation of perception on Indoor Air Quality and Indoor Environmental Quality}

\subsection{Indoor Air Quality and Indoor Environmental Quality Importance}

Workplace health is essential whether we are talking about adults, who spend at least 8 hours a day at work, or we are talking about students, for whom school is the place where they spend even 5-6 hours a day. No organization, regardless of the field in which it operates, can function without its employees, their health and their physical availability being important. Obviously, this availability is closely linked to the occupational safety measures taken within the organization, and the approach to occupational health and safety issues as an integral part of the work process, within the management system.

The approach of knowing the occupants' perception about the air inside the buildings and understanding some dissatisfactions related to air quality, respectively the reflection of poor air quality in individual health led to investigate these issues in depth, by completing a questionnaire, which was applied in the monitored public buildings.

Indoor Environmental Quality or indoor comfort is that condition of mind which expresses the degree of satisfaction with the inside environment: classroom or office. When we discuss about personal comfort, there are large variations depending on the psychological and physiological status of occupants. So, the perception could vary from person to person, the inside environmental conditions required for comfort are very different and subjective.

\subsection{Survey methodology}

During this survey, questionnaires were used, intended to capture the perception of the occupants of the investigated buildings regarding the perception of indoor air quality and a series of related symptoms. The questionnaires were adapted and used both in schools and in public buildings of the local public administration. The survey was well-accepted by all participants. The survey was voluntary and anonymous, the respondents being asked only for data on gender and age.

The questionnaire was structured in three parts. The first part was dedicated to the description of the main personal problem related to air quality, followed by the investigation of the quality of factors related to temperature and humidity, the presence of moulds, the opinion on the degree of maintenance of the classroom or office. Questions were also asked regarding the connection between IAQ and certain works carried out in the last year: renovation works, changes/improvements of the heating or cooling system, changes in the number of occupants, condition of the furniture, floors, natural lighting and natural ventilation / air conditioning system. In addition, the questionnaire investigated the symptoms that can be attributed to the quality of the air and the environment in the rooms, their frequency as well as whether these symptoms worsen or diminish as the respondent 
leaves the room. In the current context generated by the infection with the new SARS CoV2 coronavirus, the participants in the study were asked to indicate their personal perception on the connection between infection prevention measures implemented at organisation level and indoor air quality.

The end of the questionnaire was dedicated to proposals for specific measures to improve air quality in classrooms, respectively office rooms.

The survey was run by three public employees experienced in qualitative research from the City Hall of Timisoara - Environmental Directorate - members in the Project Implementation Team of "Smart and Sustainable Energy Consumption".

The research method was based on a questionnaire, adapted for the public administrative buildings and for schools.

The questionnaire was conducted on a sample of 180 participants - civil servants, parents, and teachers, using the survey method of sociological research; it was distributed by the project manager to the occupants of the investigated offices and to the principals of the involved schools. The survey was conducted in February 2021, with the participation of 151 valid respondents, representing a response rate of $83.88 \%$.

The survey was dedicated to public servants, teachers, and pupils. Initially, the questionnaire for pupils was recommended to be completed under the supervision of parents and teachers, but there were situations in which children wanted to complete the questionnaire. This approach is reinforced by the fact that there are studies indicating that students over the age of 9 can provide data on their own health, to provide information on the perception of indoor air quality and to work with simple questionnaires.

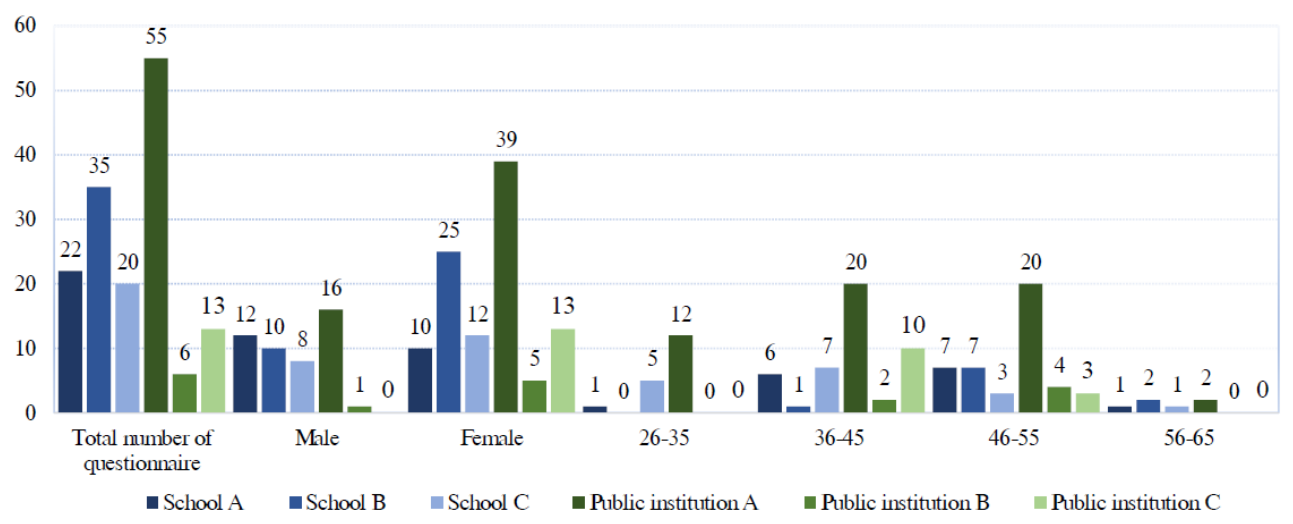

Fig. 1. The distribution of questionnaires, the survey group demography, and the respondents.

\subsection{Results}

The results of the investigation on IAQ and environmental factors inside the three schools that participated in the study demonstrate that:

- The temperature is considered too high in the school A (23\%) and in the school B (29\%), a fact that is confirmed by the temperature measurements in the classrooms, which saw results as high as $26^{\circ} \mathrm{C}$ at the end of classes;

- Humidity is considered high in school C (15\%), with measurements indicating high values, especially at the end of classes;

- Stale air is identified as a cause of discomfort in school A (18\%) and school C (25\%);

- Drafty classrooms are a problem for $23 \%$ of respondents in school A and $25 \%$ of respondents in school C; 
- The presence of unpleasant odors is identified by respondents of all three schools in a proportion ranging from $23 \%$ to $29 \%$;

- The presence of mould is indicated by respondents in school B $(29 \%)$ and school C $(15 \%)$, and especially for classes located on the basement level of schools.

- The indoor temperatures measured in the investigated rooms showed homogeneous values, ranging from a minimum of $21.6 \pm 1.3^{\circ} \mathrm{C}$ to a maximum of $24.2 \pm 1.8^{\circ} \mathrm{C}$ in all monitored buildings - classrooms and offices. These values partly fell within the $20-23^{\circ} \mathrm{C}$ range recommended for indoor environment in wintertime, but many investigated rooms exceed the maximum limit recommended by the American National Standard Institute (ASHRAE), especially at the end of classes.

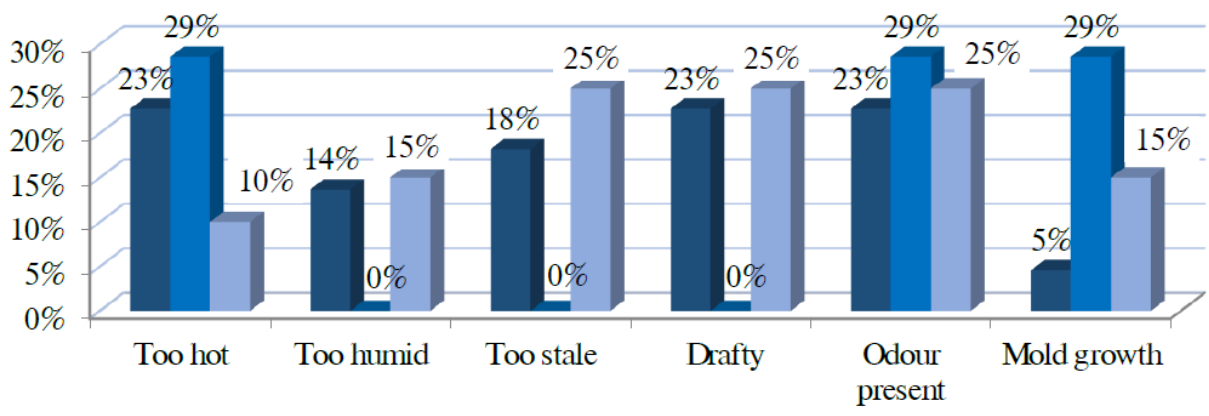

- School A $\backsim$ School B $\backsim$ School C

Fig. 2. Results on perception of pupils, teachers, and non-didactical staff regarding indoor environmental conditions in the schools.

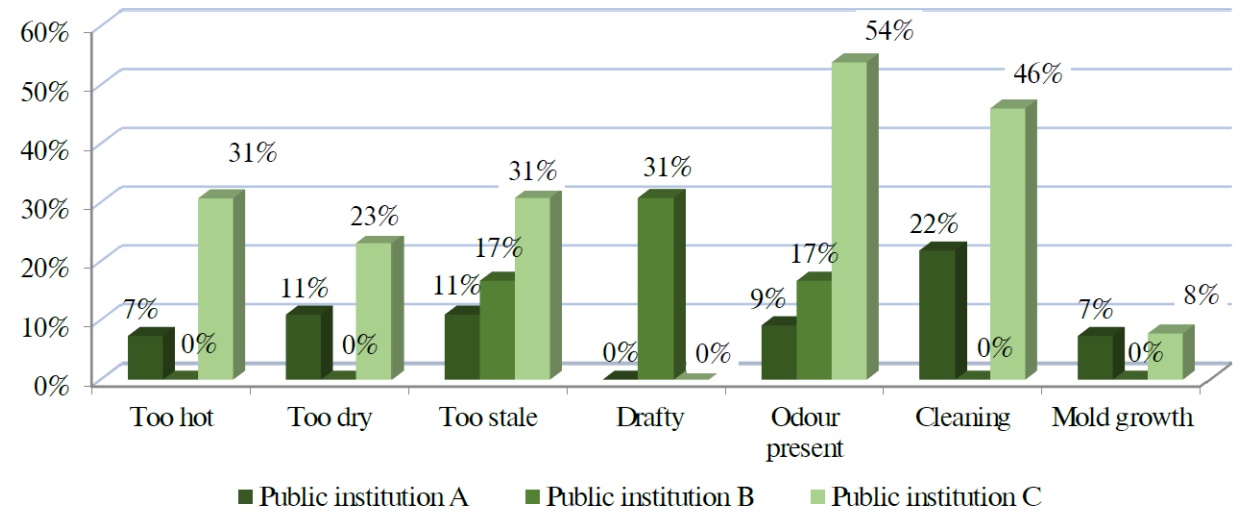

Fig. 3. Results on perception of employees on indoor environmental conditions in the municipal public buildings.

The results of the survey on IAQ and environmental factors inside the investigated municipal public buildings demonstrate that:

- The thermal discomfort felt by the occupants is high in public building $\mathrm{C} \mathrm{(31 \% ),} \mathrm{which} \mathrm{is}$ also indicated by measuring the values of ambient temperature and relative humidity $(23 \%)$. Discomfort caused by draft (31\%) and the presence of persistent odors (54\%) were also identified by a significant portion of respondents which also noted that the cleaning and maintenance activities in office spaces is not adequate (46\%). The presence of mould was indicated by $8 \%$ of respondents.

- In the public building $\mathrm{A}$, the perception regarding air quality is positive compared to building C. $7 \%$ of respondents indicated that temperature was a factor of discomfort, $11 \%$ 
that low relative humidity and the stale air were factors of discomfort, $9 \%$ that the presence of persistent odors was a factor of discomfort while 7\% identified the presence of mould as the main factor of discomfort. The level of office cleanliness is considered inappropriate by $22 \%$ of respondents, being mainly indicated the presence of dust. In the case of public building A, 16\% invoked the presence of the excess dust, which can be justified by renovation activities and maintenance work on the existing heating and cooling system. Respondents indicated that obsolete furniture, lack of sanitizing through painting the interior walls and the large number of documents stored in the offices were the main causes of unpleasant odors.

- In building B, only the presence of unpleasant odors was recorded (17\%).

Regarding the answer to the questionnaire on the possible causes of poor air quality in classrooms or offices, respondents indicated:

- Air pollution at city level - all investigated buildings are in the central area of the city;

- The age of the buildings in the case of schools A and B (heritage buildings), and of the public building A;

- Lack of ventilation and air conditioning / filtration systems in schools;

- Completion of rehabilitation and modernization works in buildings;

- Large number of employees related to offices space - for public buildings A and C;

- Lower frequency in filter replacement services in heating / cooling systems;

- Roofs with damaged parts, areas with the insulation of the building affected;

- The presence of pigeons in the attic - source of unpleasant odors;

The recommendations for improving air quality inside of the buildings were related to the maintenance activities (cleaning) of the buildings, necessity of few smaller scale investments but also to the aspect that aims to change the behavior of the occupants: rehabilitations of interior spaces, modernizations, periodic ventilation of the rooms, cleaning services in municipal public buildings, reorganization of offices, endowment with new furniture, air purifiers and organizing spaces for storing files and documents that are not accessed with high frequency/digitizing and storing data in digital format.

\section{Strengths and limitation of the research}

One of the main strengths of this survey lies in the sampling approach. In indoor air qualityrelated questionnaires, the number of pupils involved was low, and the parents were the persons used as a proxy for the secondary school pupils' perception and health symptom reporting.

The questionnaires were designed to be given to middle and high school students, to answer questions directly from the questionnaire, without mediation from parents and teachers, but this was difficult due to the suspension of classes due to measures to prevent SARS Cov-2 virus infection.

There is a possibility that there were discrepancies between those reported by students and those reported by parents in the questionnaire. The future study will address students directly, who demonstrate maturity and a good understanding of the problems related to environmental factors inside buildings, the connection between air quality in buildings and the health of occupants, the assessment of their own health, symptoms, and the connection to certain exposure situations, so that the level of accuracy of the responses is not altered by any external factor.

The questionnaires focus on classrooms and offices characteristics that tend to be associated with pollutant exposures. 


\section{Conclusions}

The present survey's objective was to monitor the microaeroflora in public buildings. A predefined questionnaire has been used as research methodology. Research results have identified and characterized: the level of IAQ in three schools and three municipal buildings and the perception of occupants on IAQ and IAP. As a general picture of the results of specialised laboratory analyses and questionnaires, some characteristics have been capitalized through the presented study:

- IAQ in all investigated buildings meet the requirements norms for microaeroflora;

- Periodic determinations of aero-microflora in schools and public institutions are recommended, air being an efficient transmission route and the most difficult environment to influence in the prevention of infections.

- The presence of conditionally pathogen bacteria in the environment of the investigated schools constitutes a higher risk for the pupils than their presence in the public buildings offices for adults, being known the higher receptivity of children to infections, because of the incomplete development of the immune system.

- The investigated buildings and rooms are comfortable for majority of the occupants, but to achieve the substantial majority (at least $80 \%$ of the occupants), improvement measures are needed.

- Controlling moisture can improve IAQ in certain areas of buildings, especially at basement level situated classrooms and offices;

- It should be highlight that some respondents encountered difficulties to assess their health status and to attribute symptoms to the IAQ of the buildings where they work or study, the symptoms being considered because of the quality of the environment in general. The survey could not detect the association between the quality of environmental factors and the reporting of symptoms, when the questionnaire question was related to the association of symptoms with attendance at school or office and when symptoms are generally experienced (e.g., without a relationship to a specific environment).

- The further studies must be conducted in the presence of real-time sensors for a complete quantitative assessment exposure profiles in the enclosed spaces where people learn and work.

- A plan to improve IAQ in the public buildings was proposed, with specific measures to increase the comfort and health of the learning and working environment.

The paper resulted (in part) from the work supported by the Interreg IPA Cross-border Cooperation Program Romania - Serbia 2014-2020, by the activities conducted in the project "Smart and Sustainable Energy Consumption" - Acronym SASEC, RORS-300 [26]. This paper and the communication reflect the views only of the authors, and the Commission cannot be held responsible for any use, which may be made of the information contained therein. We would like to express our appreciation to the Central Laboratory of Medical Analysis of the Emergency County Clinical Hospital "Pius Brinzeu" Timisoara team, for integrating us in the working team for actively participating in the works, for benefiting from learning, knowledge and all the support we needed to do this survey. We would like to express our appreciation to the public-school principals and teachers for their support.

\section{References}

1. World Health Organization, WHO guidelines for indoor air quality: selected pollutants [Online]. Available: https://www.euro.who.int/_data/assets/pdf_file/0009/128169/e94535.pdf [Accessed 28 February 2021]

2. R.F. Phalen, Inhalation Studies: Foundations and Techniques (Informa Health Care, New York, 2008) 
3. O.M. Morakinyo, M.I. Mokgobu, M.S. Mukhola, R.P. Hunter, INT J ENVIRON RES PU, 13, 6, (2016)

4. B. Andersen, J.C. Frisvad, I. Søndergaard, I.S. Rasmussen, L.S. Larsen, Appl. Environ. Microbiol, 77, 12 (2011)

5. M.A. Andersson, M. Nikulin, U. Köljalg, M.C. Andersson, F. Rainey, K. Reijula, E.L. Hintikka, M. Selkinoja-Salonen, Appl. Environ. Microbiol., 63, (1997)

6. B. Simon-Nobbe, U. Denk, V. Pöll, R. Rid, M. Breitenbach, Int. Arch. Allergy Immunol., 145 (1), 58 (2008)

7. A.P. Knutsen, R.K. Bush, J.G. Demain, D.W. Denning, A. Dixit, A. Fairs, P.A. Greenberger, B. Kariuki, H. Kita, V.P. Kurup, and collab, J. Allergy Clin. Immunol., 129, 280 (2012)

8. J. Douwes, P. Thorne, N. Pears, D. Heederik, Ann. Occup. Hyg., 47, 187 (2003)

9. K. Huttunen, A. Hyvärinen, A. Nevalainen, H. Momulainen, M.-R., Hirvonen, Environ. Health Perspective. 111, 85 (2003)

10. J. Jussila, H. Komulainen, K. Huttunen, M. Roponen, E. Iivanainen, P. Tokko, V.-M. Kosma, J. Pelkonen, M.-R. Hirvonen, M.-R. Environ. Health Perspective. 110, 1119 (2002)

11. R. Rylander, Prog. Clin. Biol. Res., 392, 79 (1995)

12. R. Rylander, J. Endotoxin Res. 8, 241 (2002)

13. V. Liebers, M. Raulf-Heimsoth, T. Brüning, Arch. Toxicol, 82, 203 (2008)

14. B. Gutarowska, M. Piotrrowska, Build. and Environ. 42, 1843 (2007)

15. D. Mudarri, W.J. Fisk, Indoor Air 17, 226 (2007)

16. C.Y. Wong, Hong Kong Medical Journal. 9, 4, 304 (2003)

17. L.D. Stetzenbach, M.P. Buttner, P. Cruz, Curr. Opin. in Biotechnol. 15 (3), 170 (2004)

18. E.C. Cole, C.E. Cook, Am. J. Infect. Control. 24 (4), 453 (1998)

19. J.W. Tang, Y. Li, I. Eames, P.K. Chan, G.L. Ridgway, J HOSP INFECT, 64 (2), 100 (2006)

20. B. Kozielska, E. Brągoszewska, D. Kaleta, Air Qual Atmos Health, 13, 131 (2020)

21. E. Brągoszewska, I. Biedroń, B. Kozielska, J.S. Pastuszka, Air Qual Atmos Health 11, 729 (2018)

22. USEPA, Introduction to Indoor Air Quality, [Online]. Available: https://www.epa.gov/indoorair-quality-iaq/introduction-indoor-air-quality. [Accessed 28 February 2021]

23. World Health Organization (WHO), Global Urban Ambient Air Pollution Database, 2016, [Online]. Available: https://www.who.int/phe/health_topics/outdoorair/databases/cities/en/. [Accessed 28 February 2021]

24. WHO, Household Air Pollution and Health, [Online]. Available: https://www.who.int/en/newsroom/fact-sheets/detail/household-air-pollution-and-health. [Accessed 28 February 2021]

25. S. Mănescu, Medical Publishing House, Bucharest, 15-37, (1989)

26. Deliverables of the project "Smart and Sustainable Energy Consumption"-Acronym SASEC, RORS-300, [Online]. Available:https://www.dmmt.ro/index.php?meniuId=28\&viewCat $=651 \& l g$ $=$ ro, https://www.primariatm.ro/2021/03/09/investigarea-calitatii-aerului/. [Accessed 25 April 2021] 